\title{
Huhungan Asma, Rinitis Alergik, Dermatitis Atopik dengan IgE Spesifik Anak Usia 6 - 7 Tahun
}

\author{
Opy Dyah Paramita, * Harsoyo $N$, ${ }^{*}$ Henry Setiawan ** \\ *Departemen Pediatri Fakultas Kedokteran Universitas Diponegoro/SMF Kesehatan RSUP Dr. Kariadi, \\ Semarang \\ **Program Magister Epidemiologi Fakultas Pasca Sarjana UNDIP, Semarang
}

\begin{abstract}
Latar belakang. Alergi adalah reaksi hipersensitivitas diperantarai oleh IgE. Manifestasi alergi adalah asma, rinitis alergik (RA) dan dermatitis atopik (DA). Salah satu pemeriksaan alergi adalah IgE spesifik, dengan diketahui jenis alergen maka kejadian alergi pada anak dapat dicegah.

Tujuan. Membuktikan hubungan jenis alergi (asma, RA, dan DA) dengan kadar IgE spesifik tungau debu rumah, kecoa, dan putih telur.

Metode. Penelitian cross sectional dilakukan Januari-April 2011 di dua sekolah dasar. Anak dengan gejala asma, rinitis alergik, dan dermatitis atopik berdasarkan kuesioner International Study of Asthma and Alle rgies in Childhood (ISAAC) dilakukan pemeriksaan IgE spesifik tungau debu rumah, putih telur, dan kecoa. Uji statistik dengan Fisher exact test, Cramers V, Lambda, dan regresi logistik dengan metode enter.

Hasil. Duapuluh enam subjek yang mengikuti penelitian ini, terdiri dari 6 subjek asma, 15RA, dan 5 DA. Hasil pemeriksaan IgE spesifik positif tungau debu rumah, kecoa, dan putih telur secara berturut-turut adalah asma 3, 2, 0; RA 7, 3, 3; dan DA 2, 1, 2. Fischer exact test pada IgE spesifik tungau debu rumah $(\mathrm{p}=1,000 ; \mathrm{PR}=1,190 ; 95 \% \mathrm{CI}=0,372-3,811)$, IgE spesifik kecoa ( $\mathrm{p}=1,000$; $\mathrm{PR}=1,190 ; 95 \% \mathrm{CI}=0,176-8,061)$, IgE spesifik putih telur ( $\mathrm{p}=0,236 ; \mathrm{PR}=0,357 ; 95 \% \mathrm{CI}=0,080-1,601)$.

Kesimpulan. Tidak terdapat hubungan yang bermakna antara jenis alergi (asma, rinitis alergik, dan dermatitis atopik) dengan kadar IgE spesifik tungau debu rumah, kecoa, dan putih telur pada anak usia 6-7 tahun dan jenis alergen terbanyak pada asma, rinitis alergik dan dermatitis atopik adalah tungau debu rumah. Sari Pediatri 2013;14(6):391-7.
\end{abstract}

Kata kunci: asma, rinitis alergik, dematitis atopik, imunoglobulin E spesifik

\footnotetext{
Alamat korespondensi:

Dr. Opy Dyah Paramita, Sp.A.Departemen Pediatri FK UNDIP/SMF Kesehatan Anak RSUP Dr Kariadi Semarang. E-mail: opydyahparamita@ yahoo.com
}

I stilah alergi digunakan pertama kali digunakan oleh Clemens tahun 1906 diartikan sebagai "reaksi pejamu yang berubah" bila terpajan dengan bahan yang sama untuk kedua kalinya atau lebih. ${ }^{1}$ Alergi adalah reaksi hipersensitivitas yang 
diinisiasi oleh mekanisme imunologis spesifik yang diperantarai oleh imunoglobulin $\mathrm{E}$ (IgE). ${ }^{2}$

Reaksi alergi dapat mempengaruhi hampir semua jaringan, atau organ dalam tubuh. Manifestasi klinis umum dari alergi termasuk asma, dermatitis atopik, rinitis alergik, dan urtikaria/angioedema. Alergi makanan dan dermatitis atopik lebih sering terjadi pada bayi dan anak-anak yang lebih muda, sedangkan asma dan rinits alergi sering terjadi pada usia yang lebih besar. Manifestasi alergi dapat mengancam hidup seperti asma berat dan reaksi anafilaksis. ${ }^{3}$

ISAAC (International Study of Asthma and Allergies in Childhood) adalah program penelitian epidemiologi didirikan pada tahun 1991 untuk menyelidiki asma, rinitis dan dermatitis atopik pada anak-anak dengan membentuk sebuah metodologi standar dan memfasilitasi kerjasama internasional yang diikuti 156 senter dari 56 negara yang berpartisipasi. Kuesioner ISAAC dibagi menjadi dua kelompok berdasarkan umur, yaitu untuk anak usia 13-14 tahun dan 6-7 tahun. ${ }^{4}$ Penelitian dengan kuesioner ISAAC pada anak sekolah dasar usia 6-7 tahun di Semarang yang dilakukan oleh Nency $^{6}$, didapatkan jumlah kasus alergi berturutturut meliputi asma $8,1 \%$, rinitis alergik $11,5 \%$, dan eksim 8,2\%.

Tes alergi telah digunakan sejak 30 tahun yang lalu. Pemeriksaan alergi meliputi tes in vitro dan in vivo. ${ }^{7}$ Pemeriksaaan in vivo berupa tes uji kulit. Pemeriksaan in vitro berupa pemeriksaan IgE spesifik. Pemeriksaan IgE spesifik digunakan sejak tahun 1990-an. Penelitian Wistiani di Semarang melaporkan bahwa alergen tersering pada asma dan rinitis alergik adalah tungau debu rumah, serpihan binatang peliharaan, kecoa, dan jamur pada pasien rawat jalan di RSUP Dr. Kariadi. ${ }^{8}$

Penelitian mengenai alergi pada anak di Indonesia pada umumnya dan khususnya di Semarang, masih sangat terbatas. Penelitian ini bertujuan untuk mengetahui hubungan $\mathrm{IgE}$ spesifik sebagai faktor risiko terjadinya asma, rinitis alergik, dan dermatitis atopik pada anak usia 6-7 tahun di Semarang. Diharapkan dengan diketahuinya jenis alergen maka pencegahan terhadap kejadian alergi pada anak dapat lebih efektif dicegah.

\section{Metode}

Penelitian cross sectional dengan kuesioner ISAAC diberikan kepada dua sekolah dasar yaitu SD Negeri bertaraf internasional, dan SD Supriyadi pada siswa kelas I. Hasil kuesioner ISAAC didapatkan anak dengan gejala asma, rinitis alergik, dan dermatitis atopik.

Besar sampel dihitung berdasarkan perhitungan besar sampel untuk penelitian cross sectional, didapatkan 26 subyek. Subyek penelitian dipilih menggunakan metode purposive sampling, siswa kelas I SD yang berdasarkan kuesioner ISAAC mempunyai gelaja asma, rinitis alergika, dan dermatitis atopik. Kriteria inklusi adalah usia usia 6-7 tahun, diketahui menderita penyakit alergi berdasarkan kuesioner ISAAC, orangtua/wali anak setuju secara tertulis anaknya ikut serta dalam penelitian. Kriteria eksklusi adalah mempunyai riwayat anafilaktik, diketahui menggunakan anti hitamin atau kortikosteroid selama 3 bulan terakhir. Subyek dilakukan pemeriksaan IgE spesifik tungau debu rumah, kecoa, dan putih telur. Kadar IgE Spesifik diukur dengan metode FEIA di Laboratorium Prodia kerjasama dengan Laboratorium Biolisa.

Analisis univariat pada data yang berskala kategorial seperti jenis kelamin anak, jenis penyakit alergi, jenis alergen, riwayat atopi dalam keluarga, dan kategori kelas titer alergen dinyatakan dengan distribusi frekuensi. Data yang berskala kontinu seperti umur, titer alergen dan sebagainya akan dinyatakan sebagai rerata dan simpang baku. Analisis bivariat yang dilakukan adalah uji Fisher exact, dan analisis risiko (risk prevalence) untuk melihat asosiasi dan besarnya risiko antara jenis alergi (asma, rinitis alergik, dan dermatitis atopik) dan kadar IgE spesifik tungau debu rumah, kecoa, dan putih telur. Selanjutnya, dilakukan analisis Cramers $V$ dan uji Lambda untuk melihat indepedency dan korelasi antara kadar IgE spesifik tungau debu rumah, kecoa, dan putih telur dengan jenis alergi. Selanjutnya, dilakukan analisis multivariat dengan regresi logistik untuk mengendalikan variabel perancu. Batas kemaknaan adalah $\mathrm{p}=0,05$, dengan interval kepercayaan 95\%.

\section{Hasil}

Penelitian melibatkan 26 anak yang mengalami gejala alergi berdasarkan kuesioner ISAAC tahap 1 yang diberikan kepada 143 anak kelas 1 di SD Negeri bertaraf internasional,dan SD Supriyadi. Seratus empat puluh tiga kuesioner yang disebarkan, peneliti 
menerima kembali 130 kuesioner. Hasil kuesioner yang dikembalikan tersebut diketahui bahwa 32 anak mengalami gejala alergi terdiri dari asma 7 , rinitis alergik 18, dan dermatitis atopik 7 anak. Dua puluh enam anak yang menjadi sampel penelitian diketahui berdasarkan hasil kuesioner ISAAC, bahwa yang memiliki gejala asma 6 , gejala rinitis alergik 15 , dan gejala dermatitis atopik 5 anak.

Pada Tabel 1, berdasarkan nilai rerata usia anak dalam bulan adalah $82,12 \pm 5,23$ dengan proporsi anak laki-laki dan perempuan sama banyaknya. Sebagian

Tabel 1. Karakteristik subyek

\begin{tabular}{lc}
\hline Karakteristik & Jumlah (n) \\
\hline Usia (rerata \pm SD) & $82,12 \pm 5,23$ \\
Jenis kelamin & \\
Laki-laki & 13 \\
Perempuan & 13 \\
Status gizi & \\
$\quad$ Kurang & 1 \\
Baik & 19 \\
Lebih & 6 \\
ASI eksklusif & \\
Ya & 7 \\
Tidak & 19 \\
Pemberian obat cacing 6 bulan sekali & \\
Ya & 7 \\
Tidak & 19 \\
\hline
\end{tabular}

besar anak memiliki gizi yang baik, meskipun ASI eksklusif hanya diberikan pada 7 anak. Pemberian

Tabel 2. Hasil pemeriksaan imunogobulin E spesifik

\begin{tabular}{|c|c|}
\hline Imunoglobulin E spesifik & $\mathrm{n}$ \\
\hline \multicolumn{2}{|l|}{ Tungau debu rumah $(\mathrm{kU} \backslash \mathrm{L})$} \\
\hline Kelas $0(<0,35)$ & 14 \\
\hline Kelas $1(0,35-0,70)$ & 1 \\
\hline Kelas $2(0,71-3,50)$ & 6 \\
\hline Kelas $3(3,51-1,75)$ & 0 \\
\hline Kelas $4(17,6-50,0)$ & 3 \\
\hline Kelas $5(50,1-100)$ & 2 \\
\hline Kelas $6(>100)$ & 0 \\
\hline \multicolumn{2}{|l|}{ Kecoa (kU\L) } \\
\hline Kelas $0(<0,35)$ & 20 \\
\hline Kelas $1(0,35-0,70)$ & 1 \\
\hline Kelas $2(0,71-3,50)$ & 2 \\
\hline Kelas $3(3,51-1,75)$ & 0 \\
\hline Kelas $4(17,6-50,0)$ & 1 \\
\hline Kelas $5(50,1-100)$ & 2 \\
\hline Kelas $6(>100)$ & 0 \\
\hline \multicolumn{2}{|l|}{ Putih telur (kU\L) } \\
\hline Kelas $0(<0,35)$ & 21 \\
\hline Kelas $1(0,35-0,70)$ & 0 \\
\hline Kelas $2(0,71-3,50)$ & 4 \\
\hline Kelas $3(3,51-1,75)$ & 1 \\
\hline Kelas $4(17,6-50,0)$ & 0 \\
\hline Kelas $5(50,1-100)$ & 0 \\
\hline Kelas $6(>100)$ & 0 \\
\hline
\end{tabular}

Tabel 3. Hubungan jenis alergi dengan kadar imunogobulin E spesifik

\begin{tabular}{lcccc}
\hline \multirow{2}{*}{ Deskripsi } & \multicolumn{2}{c}{ Cramer's V } & \multicolumn{2}{c}{ Lambda } \\
\cline { 2 - 5 } & Koef. korelasi & $\mathrm{p}$ & Koef. korelasi & $\mathrm{p}$ \\
\hline Tungau debu rumah dan jenis alergi & 0,514 & 0,088 & 0,273 & 0,066 \\
Kecoa dan jenis alergi & 0,432 & 0,286 & 0,182 & 0,141 \\
Putih telur dan jenis alergi & 0,338 & 0,203 & 0,091 & 0,308 \\
\hline
\end{tabular}

Tabel. 4 Analisis multivariat* IgE spesifik terhadap asma, rinitis alergik, dan dermatitis atopik

\begin{tabular}{lcccc}
\hline \multirow{2}{*}{ IgE spesifik } & \multirow{2}{*}{ Adj. OR } & \multicolumn{3}{c}{$95 \% \mathrm{CI}$} \\
\cline { 3 - 4 } & & Batas bawah & Batas atas & $\mathrm{p}$ \\
\hline Tungau debu rumah & 2,417 & 0,193 & 30,214 & 0,493 \\
Kecoa & 1,590 & 0,135 & 18,715 & 0,712 \\
Putih telur & 0,183 & 0,013 & 2,660 & 0,214 \\
\hline
\end{tabular}

${ }^{*}$ Diuji dengan regresi logistik dengan metode enter. Variabel perancu yang dikendalikan yaitu riwayat alergi dalam keluarga, riwayat keluarga merokok dalam satu rumah, dan pabrik sekitar rumah. 
obat cacing rutin tiap 6 bulan sekali didapatkan pada 7 anak.

Sebagian besar anak memiliki riwayat alergi dalam keluarga, yang terdiri dari riwayat alergi pada kedua orang tua didapatkan 4 anak, dan riwayat alergi pada ayah, atau ibu 19 anak, dan tidak didapatkan riwayat alergi selama kehamilan. Riwayat merokok dalam satu rumah didapatkan 10 anak, dan didapatkan pabrik kain di sekitar rumah didapatkan 2 anak. Pembersihan rumah dilakukan 1 kali/hari 7 rumah, 2 kali/hari 12, dan 3 kali/hari 7.

Proporsi kadar positif IgE spesifik tungau debu rumah, kecoa, maupun putih telur berdasarkan jenis alergi, proporsi terbanyak didapati pada anak yang menderita rinitis alergik. Kelompok kadar IgE spesifik tungau debu rumah positif terbanyak pada kelompok rinitis alergik diikuti asma, dan dermatitis atopik. Kelompok kadar IgE spesifik kecoa positif terbesar didapati pada kelompok rinitis alergik, diikuti oleh asma, dan dermatitis atopik. Kadar IgE spesifik putih telur terbanyak didapati pada kelompok rinitis alergik, diikuti oleh dermatitis atopik, dan asma. Pasien asma tidak didapati kadar IgE spesifik putih telur yang positif.

Hasil uji Fisher exact test diketahui bahwa tidak terdapat hubungan yang bermakna antara jenis alergi dengan kadar IgE spesifik tungau debu rumah, kecoa, dan putih telur. Akan tetapi, berdasarkan nilai 95\% interval kepercayaan dapat disimpulkan, bahwa anak dengan asma dan rinitis alergik cenderung merupakan faktor risiko terhadap kadar IgE spesifik tungau debu rumah dan kecoa yang positif.

Tabel 3 menunjukkan bahwa tidak terdapat hubungan dan korelasi antara jenis alergen dengan kadar IgE spesifik tungau debu rumah, kecoa, maupun putih telur. Namun, antara ketiga $\operatorname{IgE}$ spesifik tampak bahwa IgE tungau debu rumah memiliki signifikansi terkecil. Hal tersebut berarti IgE tungau debu rumah mempunyai indepedensi dan korelasi terkuat dibandingkan kecoa dan putih telur.

Setelah dianalisis dengan regresi logistik untuk mengendalikan variabel perancu didapatkan hasil, bahwa ketiga jenis IgE spesifik tidak berpengaruh secara signifikan terhadap kejadian alergi. Hasil analisis didapatkan bahwa pabrik memiliki nilai signifikansi yang terbesar dibandingkan asap rokok, dan riwayat alergi dalam keluarga untuk ketiga jenis IgE spesifik.

\section{Pembahasan}

Penelitian kuesioner ISAAC tahap 1 diberikan kepada 143 anak kelas 1 di SD Negeri bertaraf internasional, dan SD Supriyadi, sedangkan kuesioner yang dikembalikan adalah 130 kuesioner. Hasil tersebut lebih baik dibandingkan penelitian di kroasia yang juga menggunakan kuesioner ISAAC tahap I (6-7 tahun), kuesioner yang dikembalikan sebanyak 80,3\%. Hasil penelitian tersebut diketahui pula, bahwa dari 143 anak SD didapati 32 anak yang mengalami gejala alergi. ${ }^{9}$ Berbeda dengan penelitian di Taipei yang meliputi 142 sekolah dengan total jumlah kuesioner ISAAC tahap 1 adalah 25.094, didapatkan 3,694 anak yang mengalami alergi. ${ }^{10}$

Karakteristik anak yang dinilai pada penelitian kami adalah jenis kelamin, status gizi, dan usia. Variabel jenis kelamin anak menunjukkan proporsi sama besar antara laki-laki dan perempuan. Status gizi terbanyak adalah status gizi baik. Penelitian yang dilakukan pada pasien asma oleh Chamara $\mathrm{dkk}^{11}$ menyebutkan tidak terdapat perbedaan bermakna antara status gizi (BMI) dengan kejadian alergi

Usia, pendidikan, pekerjaan, dan penghasilan keluarga setiap bulan merupakan karakteristik orang tua yang dinilai pada penelitian kami. Rerata usia ayah adalah 38,12 $\pm 3,07$ tahun dan rerata usia ibu adalah $32,72 \pm 3,076$ tahun. Pendidikan ayah terbanyak adalah sarjana dan jenis pekerjaan ayah adalah wiraswasta, PNS/ABRI, dan pegawai swasta adalah sama besar. Pendidikan ibu berdasarkan jumlah berturutturutadalah sarjana, SMA, dan pasca sarjana. Sebagian besar ibu tidak bekerja. Hal tersebut sesuai dengan penelitian Chamara $\mathrm{dkk}^{11}$ yang melaporkan kejadian alergi pada anak lebih sering terjadi dan tergantung tingkat pendidikan orang tua mereka yang meliputi pendidikan ibu dan ayah, serta kondisi ekonomi yang sangat baik.

Faktor-faktor yang mempengaruhi terjadinya alergi pada anak, antara lain riwayat alergi dalam keluarga, asap rokok, dan pabrik. Pembersihan rumah terbanyak dilakukan dua kali sehari. Penelitian kami mendapatkan 23 anak memilki riwayat alergi terjadi dalam keluarga. Hal tersebut sesuai dengan penelitian asma di Turki, bahwa prevalensi asma dan alergi meningkat secara signifikan pada anak dengan riwayat keluarga alergi. ${ }^{12}$

Pabrik Apparel (pabrik kain) di sekitar lingkungan rumah didapatkan pada 2 anak yang mengalami gejala 
alergi. Bahan iritan saluran nafas seperti sulfur dioksida, nitrogen oksida, dan partikel hasil pembakaran mesin diesel menyebabkan peningkatan IgE dengan berbagai mekanisme dan inflamasi lokal pada saluran pernafasan, sehingga terjadi peningkatan kontak antara jaringan dengan alergen sehingga timbul respon imun. Riwayat keluarga merokok dalam satu rumah didapatkan pada 10 anak. Penelitian Widodo ${ }^{14}$ menyebutkan asap rokok tidak berpengaruh terhadap rinitis alergika.

Subyek dalam penelitian kamiadalah asma 6 , rinitis alergik 15, dan dermatitis atopik 5 anak. Prevalensi kejadian alergi di Semarang berdasarkan kuesioner ISAAC pada anak usia 6-7 tahun adalah asma, rinitis alergik, dan dermatitis atopik, sedangkan penelitian di Kroasia didapatkan hasil terbanyak rinitis alergik, asma, dan dermatitis atopik.

Hasil pemeriksaan IgE spesifik anak pada penelitian kami berturut-turut adalah tungau debu rumah positif 12, kecoa positif 6 , dan putih telur positif 5 anak. Penelitian di Taipei, didapatkan hasil pemeriksaan IgE spesifik terbanyak adalah Dermatophagoides pteronyssinus, D. Farinae, dan Blomia tropicaliswere, sedangkan alergi terbanyak terhadap kecoa dan bulu anjing. ${ }^{10}$

Kadar IgE spesifik dinyatakan positif bila kadar IgE spesifik pada kelas 1 dan seterusnya. Kelompok kadar IgE spesifik tungau debu rumah positif terbanyak didapati pada kelompok rinitis alergik, asma, dan dermatitis atopik.Hal yang sama didapati pada hasil pemeriksaan kadar IgE spesifik kecoa, kelompok positif terbanyak adalah rinitis alergik, asma, dan dermatitis atopik. Kadar IgE spesifik putih telur terbesar pada kelompok rinitis alergik, kemudian dermatitis. Pasien asma tidak didapati kadar IgE spesifik putih telur yang positif.

Jenis alergen terbanyak pada asma, rinitis alergi, dan dermatitis atopik adalah tungau debu rumah. Hal tersebut karena tungau debu rumah merupakan alergen utama yang terdapat pada debu rumah, dan berkembang di tempat tidur, bantal, karpet, perabot rumah tangga dengan suhu $25^{\circ} \mathrm{C}-30^{\circ} \mathrm{C}$, dan kelembaban tinggi $>60 \%$. Semarang memiliki suhu rata-rata $27,5^{\circ} \mathrm{C}$ dan kelembaban udara rata-rata $75 \%$. Anak yang tersensitisasi tungau debu rumah dengan ukuran lebih dari $2 \mu \mathrm{g} / \mathrm{g}$ debu dapat menimbulkan gejala asma. ${ }^{15}$ Penelitian di Taipei, disebutkan tungau debu rumah adalah alergen terbanyak pada anak yang menderita alergi. ${ }^{10}$
Penelitian mengenai hubungan antara IgE spesifik dengan rinitis alergik, asma, dan dermatitis atopik juga pernah dilakukan Lee dkk yang melaporkan berdasarkan pemeriksaan IgE spesifik pada asma didapatkan kadar IgE positif secara berurutan dari yang terbanyak adalah alergen inhalan, makanan, jamur, dan serbuk. Begitu pula dengan rinitis alergik didapatkan kadar IgE spesifik positif secara berurutan pada alergen inhalan, makanan, jamur, dan serbuk. Dermatitis atopik alergen terbanyak adalah alergen makanan, tungau, jamur, dan serbuk. Alergen inhalan yang diperiksa adalah tungau debu rumah, kecoa, bulu anjing, bulu kucing. Alergen makanan adalah kepiting, putih telur, udang, kacang, daging sapi, susu, jagung, ikan salmon, dan lain-lain. Alergen jamur yang diperiksa adalah Candida Albicans, Aspergillus, Cladosporium, Penicillum, dan Alternaria Alergen serbuk yang diperiksa adalah rumput, pinus, kapas, kayu putih, dan murbei.

Hubungan antara jenis alergi dan kadar $\operatorname{IgE}$ spesifik tungau debu rumah, kecoa, dan putih telur didapati hasil yang tidak bermakna. Asma dan rinitis alergik cenderung sebagai faktor risiko terjadinya kadar IgE spesifik positif pada tungau debu rumah, dan kecoa, tetapi tidak pada kadar IgE spesifik putih telur. Hal tersebut sesuai dengan penelitian Cunha ${ }^{17}$ bahwa tidak terdapat hubungan yang bermakna antara kadar IgE spesifik tungau debu rumah dengan asma. Hal yang sama juga dilaporkan oleh Martinez, ${ }^{18}$ bahwa tidak didapatkan hubungan antara kadar IgE spesifik putih telur dengan dermatitis atopik. Penelitian Syrjanen ${ }^{19}$ menunjukkan pada pasien asma dengan kadar IgE spesifik positif ( $\geq 0,35 \mathrm{kU} / \mathrm{L})$ gandum, putih telur, rumput, bulu kucing, bulu anjing, dan tungau debu rumah memprediksi terjadinya asma.

Berdasarkan uji Cramers V dan lambda, didapatkan hasil bahwa tidak terdapat hubungan maupun korelasi yang bermakna antara jenis alergi dengan kadar IgE spesifik tungau debu rumah, kecoa, dan putih telur. Hasil analisis antara jenis alergi dengan IgE spesifik, terkecil nilai signifikansinya adalah $\operatorname{IgE}$ tungau debu rumah. Hal tersebut berarti, IgE spesifik tungau debu rumah mempunyai indepedensi dan korelasi terkuat pada asma, rinitis alergik dan dermatitis atopik dibandingkan kecoa dan putih telur. Penelitian Lee $\mathrm{dkk}^{16}$ menyebutkan tungau debu rumah merupakan faktor risiko asma.

Reaksi hipersensitivitas tipe I adalah dilepaskannya berbagai mediator oleh sel mastosit dan basofil akibat 
rangsangan alergen yang terikat pada IgE yang terdapat pada permukaan sel tersebut. Granula sekretorik sel basofil dan sel mastosit mengandung mediator dan berbagai jenis sitokin. Mediator ini menarik sel-sel inflamasi lain sehingga menimbulkan manifestasi klinik alergi. Penelitian kami sebaiknya dilakukan pengambilan sampel pada saat anak mengalami gejala alergi.

Jenis alergen yang diperiksa pada penelitian kami terbatas, yaitu tungau debu rumah, kecoa, dan putih telur. Berdasarkan penelitian di beberapa negara lain, didapatkan jenis alergen lain yang dapat menjadi pencetus terjadinya alergi, seperti bulu kucing, bulu anjing, jamur, kepiting, susu sapi, udang, dan lain sebagainya.

\section{Kesimpulan}

Tidak terdapat hubungan yang bermakna antara jenis alergi (asma, rinitis alergik, dan dermatitis atopik) dengan kadar IgE spesifik tungau debu rumah, kecoa, dan putih telur pada anak usia 6-7 tahun dan jenis alergen terbanyak pada asma, rinitis alergik, dan dermatitis atopik adalah tungau debu rumah. Disarankan, penelitian selanjutnya diperlukan jumlah sampel yang lebih besar dan sama pada jenis penyakit alergi, pengambilan sampling darah dilakukan saat mengalami gejala alergi, dan ditambahkan pemeriksaan dari jenis alergen yang lain.

\section{Daftar pustaka}

1. Baratawidjaya KG. Reaksi hipersensitivitas. Dalam: Imunologi dasar. Edisi ke-7. Jakarta. Balai penerbit FKUI 2006. h. 157-61.

2. Akib AAP. Mekanismedasarpenyakitalergi. Dalam: Pediatric skin allergy and ist problem. Pendidikan kedokteran berkelanjutan LVIII di Jakarta tanggal 2021 Juni 2010. Jakarta: DepartemenIlmuKesehatanAnak FKUI-RSCM 2010. h .7-15.

3. Arshad SH, Holgate ST, Adkinson NF, Babu KS. Allergy. Atlas Medical Publishing Ltd; 2005.h.1-3.

4. ISAAC phase one. Diunduh pada tanggal 14 Juni 2010 dari: http://isaac.auckland.ac.nz/phases/phaseone/phaseone. html.

5. Koshak EA, Daghistani KJ, Jamal TS, Backer WS. Allergy workup in allergic rhinitis at Jeddah Saudia Arabia. The Internet J Health2006;5:1-7.

6. Nency YM, Prevalensi dan faktor risiko alergi pada anak usia 6-7 tahun di Semarang, [Tesis]. Semarang: UniversitasDiponegoro, 2005.

7. Quillen DM, Feller DB. Diagnosing rhinitis: allergic vs non allergic. Am Fam Physician .2006;73:1583-90.

8. Wistiani. Faktor risiko alergi pada anak di RS Dr. Kariadi Semarang. [Tesis]. Semarang: Universitas Diponegoro,2002.

9. Banac S, Tomulic KL, Ahel V, Rozmanic V, .Simundic $\mathrm{n}$, Zubovic S, dkk. Prevalence of asthma and allergic diseases in Croatian children: survey study. Croatian Med J2004;721-26.

10. Wan KS, Yang W, Wu WF. A Survey of serum specific-IgE to common allergens in primary school children of Taipei city. As pac J allergy and Immunol.2010;28:1-6.

11. Chamara RP, Wronka I, Muc M. Prevalence and correlates of allergic diseas among children. J physiol and pharmacol2008;549-56.

12. Zeyrek CD, Zeyrek F, Sevinc E, Demir E. Prevalence of asthma and allergic disease in Sanluria, Turkey, and the relation to environmental and socioeconomic factors: Is the hygiene hypothesis enough? J Investig Allergol Clin Immunol2006; 16:290-5.

13. Burmester GR, PezuttoA.Respiratory diseases. Dalam: Color atlas of immunology. Jerman: Georg Thieme Verlag; 2003. h. 214-5.

14. Widodo P. Hubungan antara rinitis alergi dengan faktorfaktor risiko yang mempengaruhi pada siswa SLTP kota Semarang usia 13-14 tahun dengan menggunakan kuesioner ISAAC (Tesis). Semarang: Fakultas Kedokteran Universitas Diponegoro, 2004.

15. Cantani A. Epidemiology and natural history of atopic diseases. Dalam: Pediatric allergy, asthma, and immunology. Berlin: Springer;2008. h. 334-63.

16. Lee CS, Tang RB, Chung RL.The evaluation allergens and allergic disease in children. J Microbiol Infect2000;33:227-32.

17. Cunha SSD, Barreto ML, Fiaccone RL, Cooper PJ, NevesNMA,Simoes SDM. Asthma cases in childhood attributed to atopyintropical area in Brazil. Rev Panam Salud Publica 2010;28:405-11.

18. Martinez TB, Ara CG, Pena JM, Esteban MM. Prediction of tolerance on the basis of quantification of egg white-specific IgE antibodies in children with egg allergy. J Allergy ClinImmunol2002;220:304-8.

19. Syrjänen AK, Reijonen TM, Romppanen J, Korhonen K, Savolainen K, Korppi M. Allergen-spesific immuno- 
Opy Dyah Paramita dkk: Hubungan asma, rinitis alergik, dermatitis atopik dengan IgE spesifik

globulin $\mathrm{E}$ anti bodies in wheezing Infants: the risk for asthma in later childhood. Pediatrics:2003;255-61.

20. Munasir Z, Suryoko EMD. Reaksi hipersensitivitas.
Dalam: Akib AAP, Munasir Z, Kurniati N.Penyunting. Buku Ajar Alergi Imunologi Anak. Edisi Ke-2. Jakarta: Balai Penerbit FKUI;2008.h.115-25. 